\title{
XÂY DỰNG BẢN ĐỒ NHẠY CẢM MÔI TRƯờNG ĐỐI VỚI SỰ CỐ TRÀN DẦU VEN BIỂN TỈNH BİNH ĐỊNH
}

\author{
LÊ VIỆT THẮNG \\ Viện Khoa học Công nghệ và Quản lý Môi truờng, Đại học Công nghiệp Thành phố Hồ Chí Minh \\ levietthang@iuh.edu.vn
}

Tóm tắt. Vùng biển và ven biển là vùng kinh tế chủ lực của tỉnh Bình Định với nhiều hoạt động du lịch, nuôi trồng thủy sản, làm muối và có hệ sinh thái đa dạng nên khi sự cố tràn dầu (SCTD) xảy ra sẽ ảnh hưởng rất lớn đến kinh tế cũng như hệ sinh thái trong khu vực. Chỉ số nhạy cảm môi trường (ESI) được phát triển để đánh giá mức độ tổn thương khi SCTD xảy ra nhằm xác định những khu vực nhạy cảm để có những biện pháp ứng phó thích hợp và giảm thiểu tác động đến môi trường. Trong nghiên cứu này, bản đồ nhạy cảm môi trường đối với SCTD được xây dựng dựa vào $\mathrm{ESI}$ của ba đối tượng bao gồm đường bờ, tài nguyên sinh vật và tài nguyên con người sử dụng, ESI của từng đối tượng được xác định dựa trên hướng dẫn của NOAA. Kết quả xây dựng bản đồ nhạy cảm môi trường đối với SCTD cho thấy đường bờ, hệ sinh thái vùng biển và ven biển tỉnh Bình Định có mức độ tổn thương cao đối với dầu tràn.

Từ khóa: Chỉ số nhạy cảm môi trường, sự cố tràn dầu, tỉnh Bình Định, NOAA

\section{MAPPING THE ENVIRONMENTAL SENSITIVITY RESPONDING TO OIL SPILLS IN BINH DINH PROVINCE}

\begin{abstract}
The coastal and marine areas are important economic areas of Binh Dinh Province, which are rich in tourism, aquaculture, salt production and diversified ecosystems, so when the oil spills occur, it will affect economic development as well as damage ecosystems. The Environmental Sensitivity Index (ESI) was developed to assess the environmental vulnerability of an oil spill and identify sensitive areas that help to preparing suitable solutions and reducing the environmental consequences. In this study, the environmental sensitivity index map was constructed based on ESI of three subjects including shoreline, biological resources and human resources which are determined based on NOAA guidelines. The results indicate that the coastlines, coastal and marine ecosystems of Binh Dinh province is highly vulnerable to oil spills.
\end{abstract}

Keywords: ESI, oil spills, Binh Dinh province, NOAA

\section{1. ĐĂT VẤN ĐỀ}

Bình Định là một tỉnh duyên hải Miền Trung Việt Nam với đường bờ biển dài $134 \mathrm{~km}$, đường biên giới quốc gia trên biển dài $115 \mathrm{~km}$, diện tích vùng nước nội thủy rộng $1.881 \mathrm{~km}^{2}$, diện tích vùng nước lãnh thổ rộng $2.557 \mathrm{~km}^{2}$ kéo dài từ Khu du lịch Bãi Bàng thành phố Quy Nhơn đến huyện Hoài Nhơn. Dọc theo bờ biển là các hoạt động du lịch, hoạt động vận tải biển với hàng nghìn tàu thuyền vận chuyển hàng hóa, tàu đánh cá và đặc biệt các hoạt động vận chuyển, kinh doanh và tồn chứa xăng dầu trên địa bàn tỉnh ngày càng gia tăng, dẫn đến nguy cơ xảy ra SCTD ở tỉnh Bình Định là rất cao. Khi SCTD xảy ra sẽ ảnh hưởng nghiêm trọng đến môi trường biển, kinh tế - xã hội, đặc biệt là ngành du lịch, ngành nuôi trồng thuỷ sản và hệ sinh thái của khu vực. Trên địa bản tỉnh Bình Định đã xảy ra một số SCTD như vào 05/2009 khoảng 100 tấn dầu không rõ nguồn gốc đã trôi dạt dọc theo bờ biển Bình Định dưới dạng vón cục, kết dính với cát thành vệt lớn cách mép nước biển khoảng $10-20 \mathrm{~m}$, tập trung chủ yếu ở hai huyện Phù Cát và Hoài Nhơn, với chiều dài khoảng $30 \mathrm{~km}$ dọc bờ biển; 07/2013 khoảng 75 tấn dầu tràn từ biển vào, phủ lên mặt nước các lồng nuôi thủy sản và trôi dạt về phía bãi tắm Quy Nhơn đã được thu gom và tập kết tại bãi rác núi bà Hỏa, phường Quang Trung để liên hệ cơ quan chức năng xử lý theo quy định; 09/2015, dầu thô trôi dạt trên biển tràn vào khu vực phía Nam xã đảo Nhơn Châu, thành phố Quy Nhơn. Vết dầu kéo dài từ cầu Cảng Cá thôn Tây đến cuối bãi biển thôn Đông, chiều dài dầu tràn ước tính $200 \mathrm{~m}$, chiều rộng $6 \mathrm{~m}$. Lượng dầu tràn ước tính khoảng 31,22 tấn gây ô nhiê̂mm môi trường, ảnh hưởng đến đời sống kinh tế và sinh hoạt, cũng như nuôi trồng và đánh bắt thủy sản của nhân dân trên địa bàn xã,... Có thể thấy nguy cơ tràn dầu trong khu vực ven 
biển tỉnh Bình Định rất cao. Do đó việc xác định những khu vực nhạy cảm và xây dựng bản đồ nhạy cảm môi trường để có những kế hoạch ứng phó thích hợp khi SCTD xảy ra là cần thiết.

Trong nghiên cứu này, chỉ số nhạy cảm môi trường (ESI - Environmental Sensitive Index) được sử dụng để xác định độ nhạy cảm môi trường cho từng khu vực khi SCTD xảy ra. ESI được tham khảo dựa trên hệ thống phân loại đường bờ Guidelines 3.0 của NOAA (Cơ quan quản lý khí quyển và đại dương Hoa kỳNational Oceanic and Atmospheric Administration) [1].

Đây là hệ thống phân loại mới của NOAA đã được áp dụng thành công ở nhiều vùng ven biển trên thế giới, điển hình như: tại khu vực bờ biển Amazon - thuộc phía Bắc của Brazil [2], kết quả cho thấy sự xuất hiện phổ biến của các khu rừng ngập mặn là môi trường sống nhạy cảm với dầu nhất (xếp hạng $\mathrm{ESI}=10 \mathrm{c}$ và 10d); Bờ biển Jbel Moussa của Maroc thuộc eo biển Gibraltar [3] cho thấy các bãi biển tại khu vực có sự đa dạng cao về địa mạo, hệ động thực vật, nhưng tài nguyên con người sử dụng lại rất hạn chế; Tại Colombia [4], chỉ số ESI được điều chỉnh theo phương pháp luận của NOAA [1] để phù hợp với điều kiện đường bờ biển của Colombia, từ đó chuẩn hóa chỉ số này nhằm áp dụng ở quy mô quốc gia, phục vụ cho việc xây dựng bản đồ nhạy cảm môi trường và các công cụ lập kế hoạch ứng phó SCTD ở vùng biển và ven biển. Bên cạnh đó, nhiều nghiên cứu về xây dựng bản đồ môi trường đường bờ ứng phó SCTD cũng được thực hiện tại nhiều tỉnh, thành phố ở Việt Nam và dựa theo phương pháp tiểp cận chỉ số ESI của NOAA. Có thể kể đến nghiên cứu của Khôi và cộng sự [5], nhóm tác giả đã xây dựng bản đồ môi trường đường bờ ứng phó SCTD cho huyện Cần Giờ dựa theo phương pháp tiếp cận chỉ số ESI của NOAA. Kết quả nghiên cứu chỉ ra rằng Cần Giờ là khu vực có nhiều khả năng chịu tác động của tràn dầu với mức độ nhạy cảm môi trường khá cao, thể hiện ở loại hình loại đường bờ ở mức nhạy cảm cao (chủ yếu là mức $8 \mathrm{~B}, 8 \mathrm{~B}, 9 \mathrm{~A}, 9 \mathrm{~B}$, và $10 \mathrm{D}$ ); Nghiên cứu khác cho thấy thêm rằng tại Bà Rịa - Vũng Tàu, khu vực ven bờ vịnh Gành Rái, cửa sông, kênh, rạch chịu ảnh hưởng của chế độ thuỷ triều, tài nguyên rừng ngập mặn, đất nuôi trồng thuỷ sản cũng như khu bảo tồn rừng được đặt ở vị trí hàng đầu trong thứ tự ưu tiên bảo vệ khi có SCTD xảy ra [6]. Ngoài ra, một số tỉnh thành như Thanh Hóa, Thái Bình cũng đã tiến hành xây dựng bản đồ nhạy cảm môi trường ứng số sự cố tràn dầu theo hướng dẫn của NOAA dựa trên 3 yếu tố chính là ESI đường bờ, ESI gần bờ và ESI trên bờ $[7,8]$.

Mục tiêu của nghiên cứu này nhằm xây dựng bản đồ nhạy cảm môi trường đối với SCTD tại vùng ven biển tỉnh Bình Định dựa trên phương pháp tiếp cận của NOAA (NOAA, 2002) nhằm xác định mức độ nhạy cảm của từng khu vực khi SCTD xảy ra, làm cơ sở quan trọng cho việc thực hiện kế hoạch ứng phó SCTD vùng ven biển và ven cửa sông, từ đó giảm thiểu tác hại và phát triển bền vững vùng bờ tỉnh Bình Định.

\section{KHU VỰC NGHIÊN CÚU}

Khu vực nghiên cứu bao gồm một phần vùng biển, các huyện ven biển tỉnh Bình Định: huyện Hoài Nhơn (421 km2), huyện Phù Mỹ (556 km2), huyện Phù Cát (681km2), huyện Tuy Phước (220km2), TP. Quy Nhơn $(286 \mathrm{~km} 2)$ và được giới hạn như trong hình 1.

Vùng có khí hậu nhiệt đới ẩm, mưa mùa. Nhiệt độ trung bình năm 26 - 270C. Lượng mưa trung bình năm $1.600-3.000 \mathrm{~mm}$, phân bố theo mùa rõ rệt. Mùa mưa (từ tháng 8 đến tháng 12 ) tập trung $70-75 \%$ lượng mưa cả năm, lại trùng với mùa bão nên thường xuyên gây ra bão, lụt. Mùa khô kéo dài gây nên hạn hán ở nhiều nơi. Lượng bốc hơi trung bình hàng năm là $1.000 \mathrm{~mm}$, chiếm $50-55 \%$ tổng lượng mưa. Độ ẩm tương đối trung bình hàng năm là $79-83 \%$.

Khu vực nghiên cứu có $134 \mathrm{~km}$ đường bờ biển với nhiều đảo, vũng, vịnh và các cửa biển rất thuận lợi xây dựng cảng biển. Các bến cảng biển chính đều tập trung ở TP. Quy Nhơn và khu vực tiếp giáp đầm Thị Nại. Cụm cảng biển Quy Nhơn có tầm quan trọng chiến lược về kinh tế - xã hội, an ninh quốc phòng của tỉnh Bình Định, khu vực miền Trung và khu vực Tây Nguyên. 


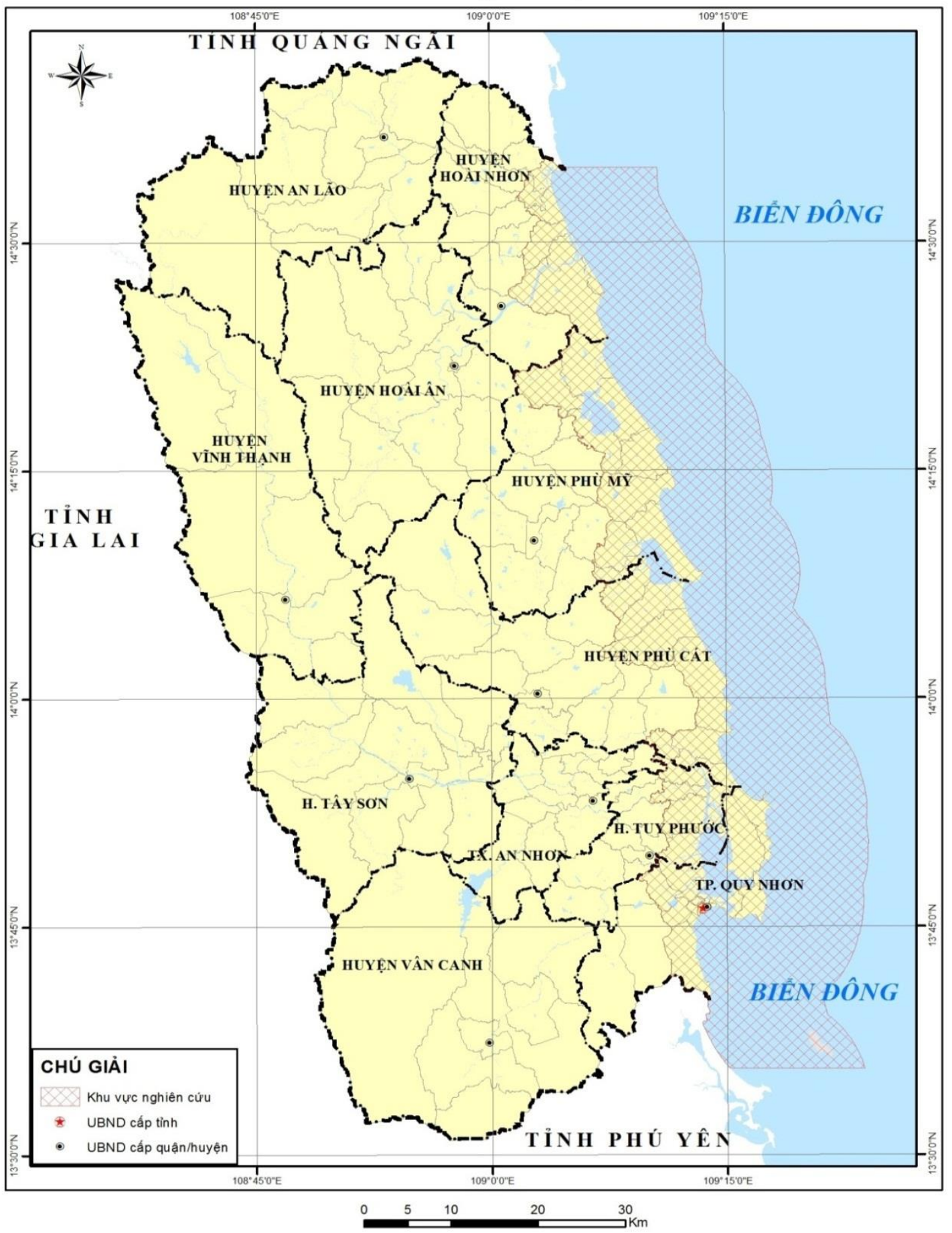

Hình 1: Khu vực nghiên cứu

\section{PHƯƠNG PHÁP NGHIÊN CÚU}

Bản đồ nhạy cảm môi trường do tràn dầu được xây dựng trước khi xảy ra SCTD và được xây dựng dựa vào chỉ số nhạy cảm môi trường (ESI). ESI của một đối tượng được xác định dựa vào mức độ nhạy cảm của đối tượng đó với dầu tràn. Các đối tượng cần thể hiện trên bản đồ nhạy cảm môi trường do dầu tràn được chia thành 3 loại:

- Nhạy cảm đường bờ: phụ thuộc vào mức độ nguy hại của dầu và mức độ dễ dàng làm sạch dầu.

- Tài nguyên sinh vật: đặc biệt là các loài và sinh cảnh nhạy cảm với dầu (như cỏ, rong, san hô, rừng ngập mặn, bãi triều, bãi cá, tôm, thú, chim, bò sát,...). 

TİNH BİNH ĐỊNH

- Tài nguyên con người sử dụng (bao gồm tài nguyên thiên nhiên do con người sử dụng và tài nguyên nhân tạo) gồm các khu vực có giá trị nghỉ dưỡng cao (khu du lịch, bãi tắm), khu di sản, vườn quốc gia, khu bảo tồn, sân chim, đồng muối, nơi nuôi trồng thuỷ hải sản, các cơ sở kinh tế (cảng, sân bay, ...), di tích văn hoá, khảo cổ, đô thị, khu dân cư tập trung...

Việc xác định chỉ số nhạy cảm ESI được tham khảo dựa trên hệ thống phân loại đường bờ Guidelines 3.0 của NOAA (NOAA, 2002), các kiểu đường bờ được phân loại rõ ràng dựa trên hình thái các dạng đường bờ để phân vùng nhạy cảm tràn dầu và được chia thành các cấp độ nhạy cảm từ 1 đến 10 trong đó cấp 10 có mức độ nhạy cảm cao nhất và cấp 1 có mức độ nhạy cảm thấp nhất. Ngoài ra, tùy vào điều kiện môi trường ở từng khu vực có thể có một số loại phụ $(\mathrm{A}, \mathrm{B}, \mathrm{C}, \mathrm{D})$. Đối với các loại bờ biển khác nhau (các hệ sinh thái sông, hồ..) chỉ số nhạy cảm môi trường ESI có thể được điều chỉnh cho từng khu vực. Bên cạnh đó, việc phân loại các mức độ đường bờ còn phụ thuộc vào mối quan hệ của các yếu tố ảnh hưởng đến môi trường đường bờ như sự tiếp xúc với năng lượng sóng và thủy triều; độ dốc của bờ biển; loại chất nền và năng suất sinh học.

Tuy nhiên Guidelines 3.0 là một hệ thống phân loại đường bờ của Mỹ, các chỉ số đánh giá cũng dựa trên các đặc trưng đường bờ của vùng biển khu vực Bắc Mỹ, nên trong khi xác định chỉ số ESI với Bình Định nói riêng và Việt Nam nói chung cần tìm ra những nét tương đồng của dạng đường bờ địa phương đó với dạng bờ được nói đến trong Guidelines 3.0. Công tác phân tích và sàng lọc giúp ta đưa ra được bảng các chỉ số nhạy cảm đường bờ phù hợp với đặc trưng đường bờ tỉnh Bình Định và từ đó xác định chỉ số ESI cho từng phân đoạn đường bờ tương ứng. Các dạng đường bờ cụ thể ở Bình Định được trình bày trong Bảng 1.

Bảng 1: Các dạng đường bờ tỉnh Bình Định theo NOAA

\begin{tabular}{|c|c|c|c|c|}
\hline STT & Loại Đường Bò̀ & ESI & Màu thể hiện & $\begin{array}{c}\text { Mức độ } \\
\text { nhảy cảm }\end{array}$ \\
\hline 1 & Bờ đá phơi lộ & $1 \mathrm{~A}$ & & \multirow{4}{*}{ Thấp } \\
\hline 2 & Đường bờ với công trình nhân tạo rắn phơi lộ & $1 \mathrm{~B}$ & & \\
\hline 3 & Đường bờ kiểu thềm đá lộ ra biển & $2 \mathrm{~A}$ & & \\
\hline 4 & Đường bờ tiếp xúc với vách núi, sườn dốc bằng đất sét & 2B & & \\
\hline 5 & Bờ có các bãi cát mịn đến vừa & $3 \mathrm{~A}$ & & \multirow{3}{*}{$\begin{array}{l}\text { Trung bình } \\
\text { thấp }\end{array}$} \\
\hline 6 & Đường bờ cát sườn dốc với độ dốc lớn & 3B & & \\
\hline 7 & Bờ có bãi cát hạt trung bình và thô & 4 & & \\
\hline 8 & Bờ biển cát và sỏi hỗn hợp & 5 & & Trung bình \\
\hline 9 & Bờ sỏi cuội & $6 \mathrm{~A}$ & & \multirow{2}{*}{$\begin{array}{c}\text { Trung bình } \\
\text { cao }\end{array}$} \\
\hline 10 & Bờ có cấu trúc Riprap & $6 \mathrm{~B}$ & & \\
\hline 11 & Bờ có bãi triều phẳng phơi lộ & 7 & & \multirow{3}{*}{$\mathrm{Cao}$} \\
\hline 12 & Bờ có công trình nhân tạo rắn bị khuất & $8 \mathrm{~B}$ & & \\
\hline 13 & Bờ đá có cấu trúc Riprap khuất & $8 \mathrm{C}$ & & \\
\hline 14 & Bãi triều phẳng bị khuất & $9 \mathrm{~A}$ & & \multirow{5}{*}{ Rất cao } \\
\hline 15 & Bờ thấp phủ thực vật & $9 \mathrm{~B}$ & & \\
\hline 16 & Đất ngập nước mặn hoặc lợ & $10 \mathrm{~A}$ & & \\
\hline 17 & Đất ngập nước ngọt & $10 \mathrm{~B}$ & & \\
\hline 18 & Rừng ngập mặn & $10 \mathrm{D}$ & & \\
\hline
\end{tabular}

Đối với tài nguyên sinh vật và tài nguyên con người sử dụng ESI được phân thành 6 cấp độ với mức nhạy cảm tăng dần dựa vào trữ lượng, mức độ phân bố và khai thác của từng loại tài nguyên (Bảng 2). 

TİNH BİNH ĐỊNH

Bảng 2: Chỉ số nhạy cảm tài nguyên sinh vật và tài nguyên con người sử dụng

\begin{tabular}{|c|c|c|c|c|}
\hline STT & Mô tả & ESI & Màu thể hiện & $\begin{array}{c}\text { Mức độ nhạy } \\
\text { cảm }\end{array}$ \\
\hline 1 & $\begin{array}{l}\text { Chưa có giá trị về mặt sinh thái cũng như kinh tế xã } \\
\text { hội. Dễ ứng cứu và làm sạch dầu tràn tại khu vực bờ } \\
\text { biển. }\end{array}$ & 1 & & Thấp \\
\hline 2 & $\begin{array}{l}\text { Có giá trị trung bình về mặt sinh thái cũng như kinh } \\
\text { tế xã hội. Dễ ứng cứu và làm sạch dầu tràn tại khu vực } \\
\text { bờ biển. }\end{array}$ & 2 & & $\begin{array}{c}\text { Trung bình } \\
\text { thấp }\end{array}$ \\
\hline 3 & $\begin{array}{l}\text { Có giá trị sinh thái và kinh tế xã hội, nhưng ít có khả } \\
\text { năng bị ảnh hưởng. Khả năng ứng cứu, làm sạch dầu } \\
\text { tràn khu vực bờ biển ở mức độ trung bình. }\end{array}$ & 3 & & Trung bình \\
\hline 4 & $\begin{array}{l}\text { Có giá trị sinh thái hoặc kinh tế xã hội tương đối cao. } \\
\text { Chịu ảnh hưởng trực tiếp nên tương đồi khó ứng cứu, } \\
\text { làm sạch tại khu vực bờ biển nếu bị dầu tràn vào. }\end{array}$ & 4 & & Trung bình cao \\
\hline 5 & $\begin{array}{l}\text { Có giá trị sinh thái hoặc kinh tế xã hội tương đối cao. } \\
\text { Chịu ảnh hưởng trực tiếp hoặc gián tiếp nề khó ứng } \\
\text { cứu, làm sạch tại khu vực bờ biền nếu bị dầu tràn vào. }\end{array}$ & 5 & & $\mathrm{Cao}$ \\
\hline 6 & $\begin{array}{l}\text { Có giá trị về mặt sinh thái và kinh tế xã hội cao và } \\
\text { nhiều khả năng chịu ảnh hượng trực tiếp do dầu tràn. } \\
\text { Khả năng ứng cứu, làm sạch tại khu vực bờ biển khó } \\
\text { hơn cả và phải mất nhiều thời gian. }\end{array}$ & 6 & & Rất cao \\
\hline
\end{tabular}

Quy trình thành lập bản đồ nhạy cảm môi trường đối với SCTD khu vực nghiên cứu được trình bày trong Hình 2.

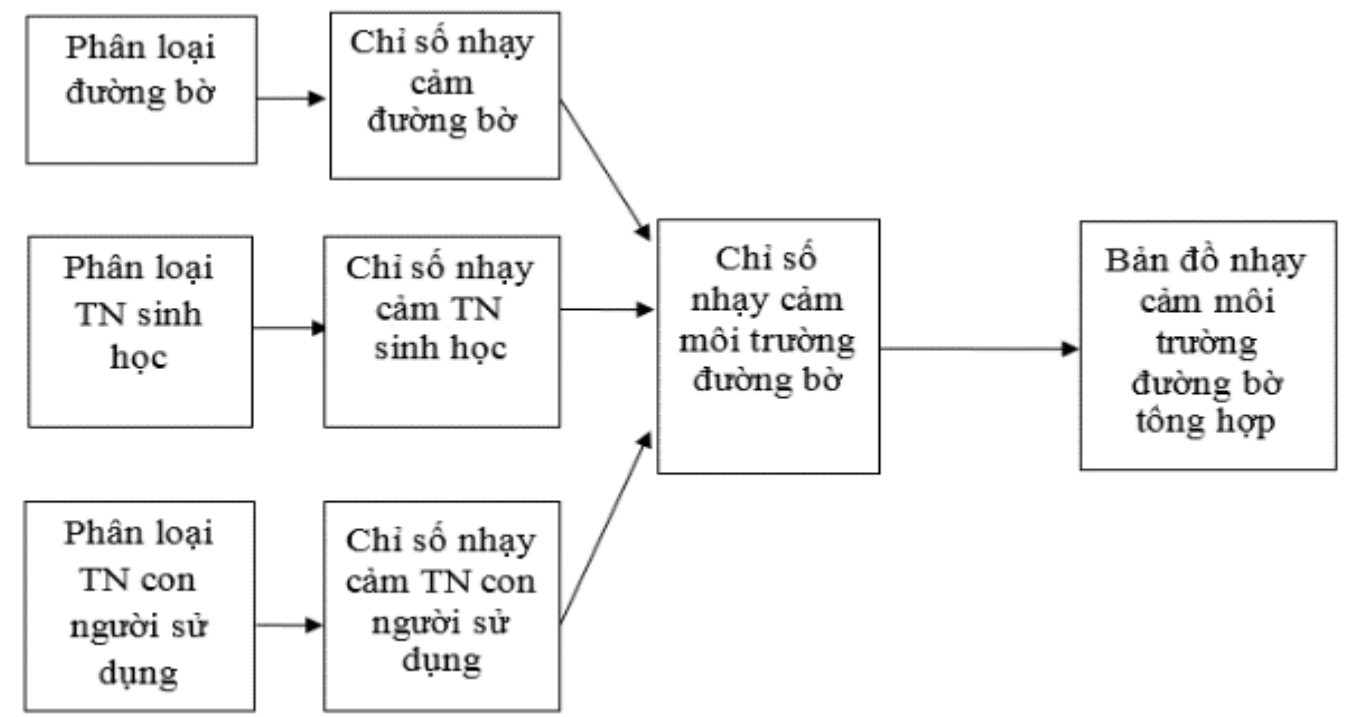

Hình 2: Cơ sở thành lập bản đồ nhạy cảm môi trường

Để xây dựng bản đồ nhạy cảm cần tiến hành phân loại sơ bộ đường bờ dựa vào bản đồ cơ sở và hình ảnh vệ tinh để nhận định mức độ nhạy cảm ESI phù hợp với từng khu vực trước khi thực hiện khảo sát thực địa. Đối với mức độ nhạy cảm tài nguyên sinh vật nghiên cứu sử dụng các bản đồ hiện trạng sử dụng đất, hiện trạng sản xuất nông - lâm - ngư nghiệp được thu thập từ Sở Tài nguyên và Môi trường, Sở Nông nghiệp và Phát triển nông thôn, kết hợp với các kết quả đề tài nghiên cứu khác có liên quan trên địa bàn tỉnh Bình Định. Đối với tài nguyên con người sử dụng nghiên cứu sử dụng bản đồ hành chính và hiện trạng sử dụng đất thu thập từ Sở Tài nguyên và Môi trường, kết hợp với ảnh vệ tinh và các tài liệu liên quan đến tài nguyên nhân sinh để phân loại.

Công tác khảo sát thực địa đường bờ bao gồm cả khảo sát trên không bằng các thiết bị hỗ trợ như flycam và xác minh thực tế mặt đất. Việc khảo sát thực tế được tiến hành trong khoảng thời gian thủy triều xuống để có thể đánh giá diện tích tối đa của bãi triều. Phương pháp điều tra khảo sát thực địa được sử dụng để xác định rõ các loại đường bờ, các loại tài nguyên trên bờ và ven bờ nhằm phục vụ cho việc đánh giá các 
chỉ số nhạy cảm cũng như xác định các vùng có thể bị hy sinh, các khu vực có thể chứa, tập kết dầu... Việc điều tra khảo sát được tiến hành theo phương pháp điều tra khảo sát bổ sung có trọng điểm, chứ không phải những cuộc điều tra tổng hợp quy mô lớn nhằm thu thập tài liệu chung trên diện rộng. Trên cơ sở những số liệu tin cậy này sẽ xây dựng và kiểm định lại với các tài liệu đã kế thừa được.

\section{KẾT QUẢ VÀ THẢO LUẬN}

\subsection{Chỉ số nhạy cảm đường bờ}

Đường bờ được phân loại dựa trên các hiểu biết về các đặc tính vật lý và sinh học của môi trường bờ chứ không chỉ tính đến dạng và kích thước vật chất cấu thành đường bờ. Các mối quan hệ giữa các quá trình vật lý, dạng vật chất và tài nguyên sinh học đi kèm tạo ra các dạng đường bờ riêng biệt với các phương thức vận chuyển vật chất, cách thức vận chuyển dầu và tác động đến tài nguyên sinh học riêng biệt.

Các dạng đường bờ ven biển Bình Định chiếm ưu thế nhất là bãi triều phẳng phơi lộ (dạng 7), nguyên nhân là do địa hình ở vùng đồng bằng ven biển thấp, có sự bồi tụ trầm tích từ sông và đặc biệt bờ biển ở đây mang đặc tính tích tụ - mài mòn, ít sóng lớn, chính sự tích tụ trầm tích đã tạo nên địa hình bãi triều. Ngoài ra, các dạng đường bờ đất ngập nước mặn cũng chiếm ưu thế, do ở đây có nhiều vùng vịnh hở, kết hợp thủy triều cao tạo nên vùng đất ngập nước rộng lớn. Kết quả phân loại đường bờ cụ thể cho từng khu vực trong tỉnh được trình bày trong Bảng 3 .

Bảng 3: Đặc trưng đường bờ các huyện ven biển tỉnh Bình Định

\begin{tabular}{|c|c|c|}
\hline $\begin{array}{l}\text { Khu } \\
\text { vụ̣c }\end{array}$ & $\begin{array}{l}\text { Thành phố, } \\
\text { huyện, thị } \\
\text { xã }\end{array}$ & Đặc trưng đường bò̀ \\
\hline \multirow[b]{2}{*}{1} & Hoài Nhơn & $\begin{array}{l}\text { Phân biệt được } 5 \text { dạng đường bờ. Trong đó: } \\
+\quad \text { Dạng 7: chiếm ưu thế kéo dài từ cửa Tam Quan tới cửa Hà Ra. } \\
+\quad \text { Dạng 9B: phân bố nhiều dọc theo sông Lại Giang, sông Tam Quan và cửa sông Tam } \\
\text { Quan. } \\
+\quad \text { Dạng 4, 8B, 8C: xuất hiện với tần số nhỏ ở khu vực này. }\end{array}$ \\
\hline & Phù Mỹ & $\begin{array}{l}\text { Phân biệt được } 7 \text { dạng đường bờ. } \\
+\quad \text { Dạng 1A: Hòn Nhàn, Hòn Nước, Hòn Tranh, Mũi Lan. } \\
+\quad \text { Dạng 3B: xuất hiện ở ven vịnh Nước Ngọt và đầm Trà Ổ. } \\
+\quad \text { Dạng } 4 \text { và 5: xuất hiện len lỏi ven bờ biển tại Mũi rồng. } \\
+\quad \text { Dạng 7: phân bố dọc bờ biển từ cửa Hà Ra đến cửa Đề Gi. } \\
+\quad \text { Dạng 10B và 9B: tập trung ở đầm Trà Ố, Vịnh Nước Ngọt. }\end{array}$ \\
\hline \multirow[b]{2}{*}{2} & Phù Cát & $\begin{array}{l}\text { Phân biệt được } 4 \text { dạng đường bờ. } \\
+ \text { Dạng 1: Núi Ông Lốp, Núi Bà, Hòn Dựng. } \\
+ \text { Dạng } 7: \text { phổ biến nhất phân bồ dọc theo chiều bờ biển từ cửa Đề Gi tới Hòn Dựng. } \\
+ \text { Dạng } 8 \mathrm{C} \text { và } 9 \mathrm{~B}: \text { dọc theo các con sông. }\end{array}$ \\
\hline & Tuy Phước & $\begin{array}{l}\text { Phân biệt được } 8 \text { dạng đường bờ. Đây là nơi phân bố nhiều dạng đường bờ nhất ở tỉnh } \\
\text { Bình Định, vì vậy có thể xem Tuy Phước là khu vực đặc trưng và đại diện rõ ràng nhầt } \\
\text { về các dạng đường bờ ở Bình Định. Do khu vực có nhiều dạng địa hình từ đồng bằng } \\
\text { ven biển đển các đầm, vũng vịnh tạo nên nét đặc trưng riêng biệt và đa dạng sinh học } \\
\text { cao. } \\
+ \text { Dạng 1: phân bố nhiều, dọc bờ biển kéo dài từ Eo Gió đến Vịnh Quy Nhơn } \\
+ \text { Dạng } 4 \text { và 5: xuất hiện ít, len lỏi ven bờ. } \\
+ \text { Dạng 6: một đoạn ngắn ở bãi Đài Xuân } \\
+ \text { Dạng 7: là một trong những dạng đường bờ chủ yếu của huyện Tuy Phước, xuất } \\
\text { hiện ở khu vực kéo dài từ Hòn Dựng đến Eo Gió. } \\
+ \text { Dạng 9B: xuất hiện khá nhiều ở Vịnh Quy Nhơn và ven đầm Thị Nại. } \\
+ \text { Dạng 10: thuộc dạng đường bờ chủ yếu ở Tuy Phước, xuất hiện bao quanh Vịnh } \\
\text { Quy Nhơn và ven đầm Thị Nại. } \\
+ \text { Dạng 10D: đầm Thị Nại. }\end{array}$ \\
\hline
\end{tabular}




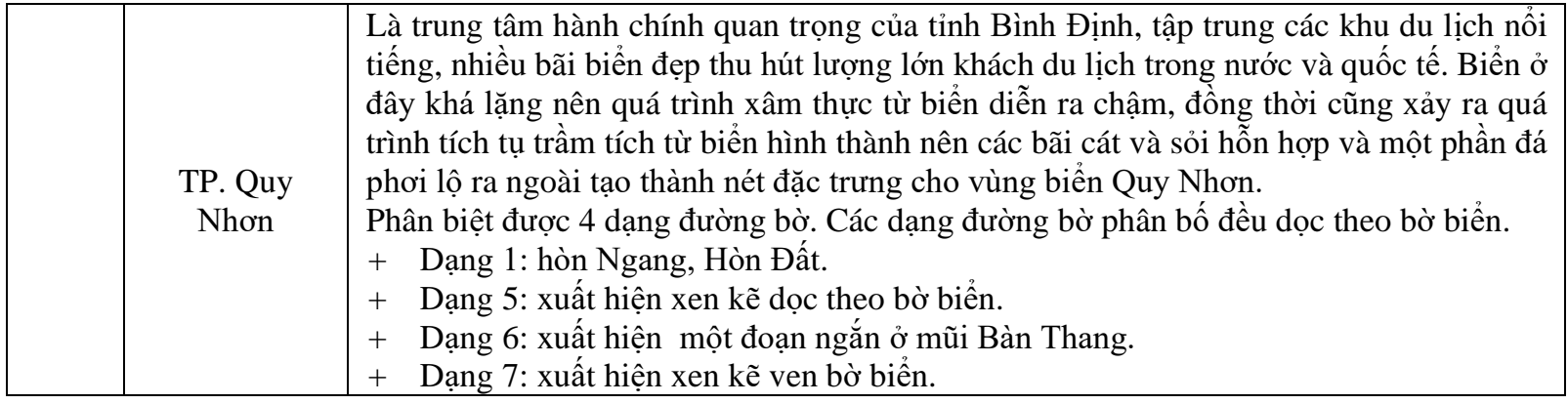

\subsection{Chỉ số nhạy cảm tài nguyên sinh vật}

Môi trường biển tỉnh Bình Định có tính đa dạng sinh học cao và môi trường sống luôn bị xáo trộn. Dầu tràn là nguyên nhân đe dọa đối với môi trường sống, dinh dưỡng và sự sống của nhiều loài sinh vật, ảnh hưởng tới đa dạng sinh học biển. Mức độ ảnh hưởng của sự cố dầu tràn lên tài nguyên sinh vật được ước tính bằng chỉ số nhạy cảm tài nguyên sinh vật.

- San hô: Bình Định có độ dốc bờ biển nhỏ, nước nông, có nhiều đảo nhỏ là nơi lý tưởng để cho rạn san hô sinh sản và phát triển. Do tính đa dạng sinh học cao, nguồn lợi kinh tế - môi trường to lớn nên mức độ nhảy cảm sinh học của san hô đối với SCTD rất cao với $\mathrm{ESI}=6$.

- Cỏ biển: là nơi sinh sản, trú ẩn của nhiều loài sinh vật biển khác như: rong biển, động vật đáy, cá biển, bò sát biển, đông vật không xương sống,...mang lại giá trị cao cả về môi trường, đa dạng sinh học lẫn kinh tế nên sự tác động của tràn dầu đến cỏ biển là rất lớn nên chỉ số nhạy cảm sinh học của cỏ biển là 6 (ESI=6), thuộc mức nhảy cảm rất cao.

- Rừng ngập mặn: là một môi trường phức hệ rất nhạy cảm, kết hợp nhiều loài. Môi trường sống của các loài tôm, cá có giá trị thương mại và cung cấp chuỗi thức ăn, bảo vệ đường bờ tránh khỏi sự xói mòn; dầu có thể lưu lại trong môi trường rừng ngập mặn, đặc biệt ở những nơi ít có tác động triều; quá trình thu hồi và làm sạch dầu có thể kéo dài đến vài năm; đặc biệt môi trường rừng ngập mặn rất nhạy cảm với chất phân tán nên mức độ nhạy cảm rất cao (ESI=6).

- Nuôi trồng thủy sản: Đa số các vùng nuôi trồng thủy sản có mức độ nhạy cảm từ trung bình đến rất cao ứng với $\mathrm{ESI}$ từ 3 đến 6.

Kết quả cụ thể được trình bày trong bảng 4.

Bảng 4: Chỉ số nhạy cảm tài nguyên sinh vật khu vực ven biển tỉnh Bình Định

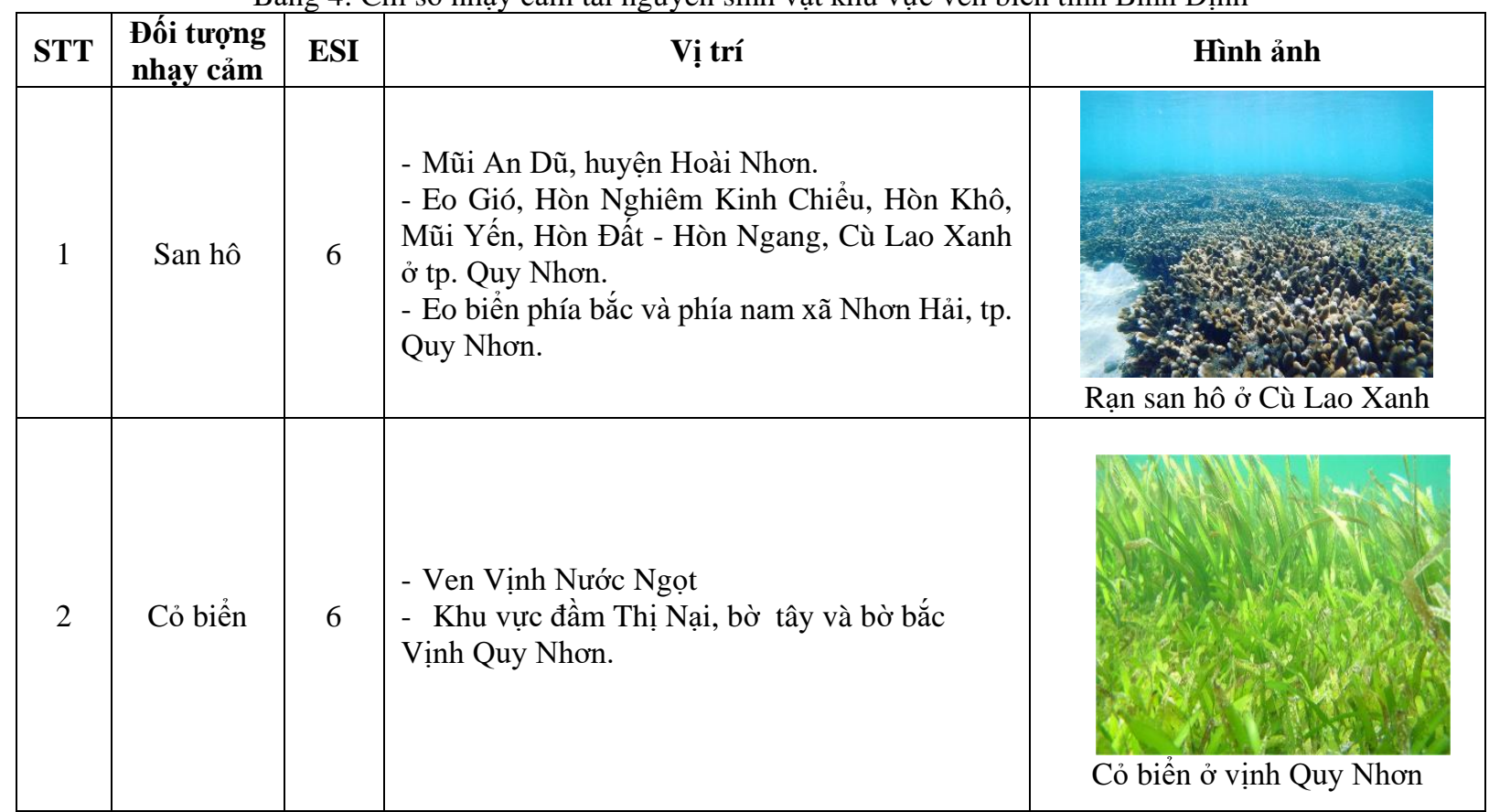



TİNH BİNH ĐỊNH

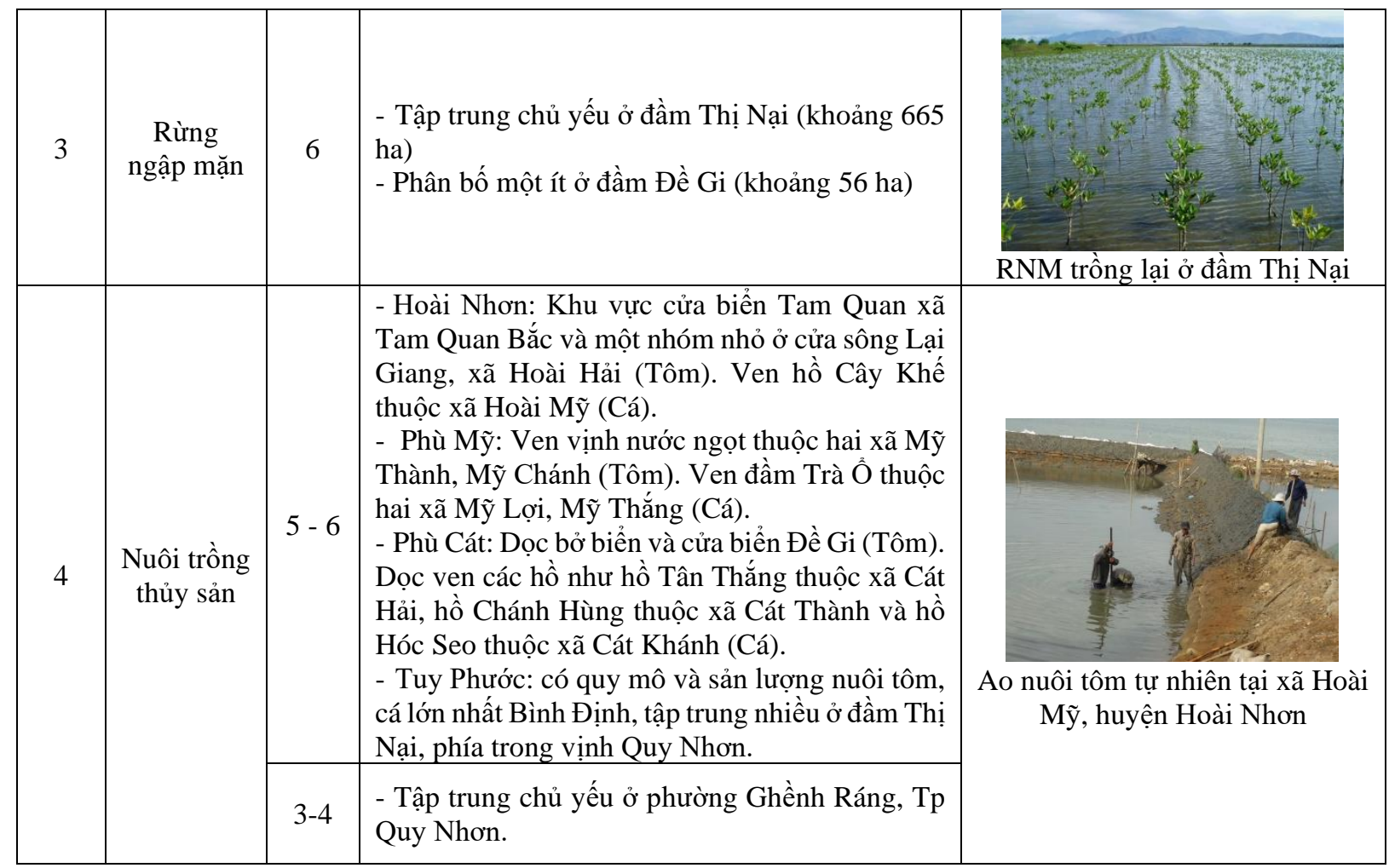

\subsection{Chỉ số nhạy cảm tài nguyên con người sử dụng}

Chỉ số nhạy cảm tài nguyên con người sử dụng bao gổm chỉ số nhạy cảm tài nguyên thiên nhiên con người sử dụng và tài nguyên nhân tạo. Do mỗi đối tượng chịu tác động của tràn dầu khác nhau nên chỉ số nhạy cảm đối với từng đối tượng là khác nhau với ESI từ 1 đến 6.

Tài nguyên con người sủ dụng

- Đất kinh doanh, du lịch: Ngành Du lịch là một trong những ngành kinh tế quan trọng của tỉnh, đem lại nhiều việc làm cho người dân địa phương, trong đó du lịch biển là một trong những thế mạnh

đặc trưng của tỉnh. Các SCTD có khả năng gây ô nhiễm các khu vực ven bờ, các bãi biển du lịch, các hòn đảo, ảnh hưởng đến các hoạt động vui chơi giải trí như tắm, du thuyền, bơi lội. Do vậy, tràn dầu là một trong những nguy cơ đe dọa ngành du lịch và tác động tới kinh tế tỉnh nên có chỉ số nhạy cảm môi trường từ mức trung bình cao đến rất cao $(\mathrm{ESI}=5-6)$, phụ thuộc vào vị trí và đặc điểm hoạt động của từng khu vực.

- Đất rừng: Rừng phòng hộ ở khu vực ven biển và đầu nguồn là những đối tượng dễ bị tác động nhất của tràn dầu, tùy thuộc vào vị trí của rừng mà mức độ nhạy cảm sẽ khác nhau (ESI=2-4).

- Khu vực làm muối: làm muối là một nghề có truyền thống lâu đời ở Bình Định với sản lượng khai thác muối khá cao. Khi SCTD xảy ra sẽ ảnh hưởng lớn đến hoạt động làm muối do phải sử dụng trực tiếp nguồn nước biển nên mức độ nhạy cảm cao (ESI=4-5).

- Khu vực canh tác lúa và hoa màu ven biển: Dầu tràn tác động đến nguồn nước tưới phục vụ canh tác, gây ảnh hưởng đến khả nguồn cung cấp lương thực thực phẩm của khu vực, tuy nhiên có thể thay thế bằng nguồn nước sạch khác nên mức độ nhạy cảm ở mức trung bình (ESI=2-4).

- Khu bảo tồn: Tại các khu bảo tồn luôn có những sinh vật và sinh cảnh quý hiếm cần được bảo vệ, dầu tràn phá hủy cấu trúc hệ sinh thái làm ảnh hưởng nghiêm trọng đến cân bằng tự nhiên của của các loài. Đây là vùng cực kì nhạy cảm với SCTD nên mức độ nhạy cảm cao với $\mathrm{ESI}=4-6$.

Tài nguyên nhân tạo

- Khu công nghiệp: các khu công nghiệp là những đối tượng ít bị tác động khi có SCTD xảy ra, chủ yếu các công ty bị thiệt hại về mặt kinh tế nên mức độ nhạy cảm của các khu công nghiệp ở mức trung bình với $\mathrm{ESI}=2-4$.

- Khu dân cư: Các nguồn tài nguyên chủ yếu tập trung ở khu vực ven biển kéo theo sự phân bố dân cư sẽ tập trung đông để sinh sống và làm kinh tế, khai thác nguồn tài nguyên đất để xây dựng nhà ở. Những khu 
vực đó tuy thuận lợi nhưng cũng có mặt tiêu cực là khi xảy ra SCTD người dân có thể chịu tác động trực tiếp (ô nhiễm nguồn nước sinh hoạt) hoặc gián tiếp (khó khăn trong sản xuất kinh doanh),...

\subsection{Bản đồ nhạy cảm môi trường đường bờ tỉnh Bình Định}

Bản đồ nhạy cảm môi trường tỉnh Bình Định được thể hiện trong phạm vi ven biển, phía Bắc giáp tỉnh Quảng Ngãi, phía Nam giáp tỉnh Phú Yên trải dài trong khoảng 134 km bờ biển. Để thuận lợi cho quá trình phân loại đường bờ và phân tích, đánh giá mức độ nhạy cảm đường bờ, nghiên cứu chia tỉnh Bình Định ra làm 2 khu vực: khu vực 1 (khu vực phía bắc gồm một số xã ven biển thuộc huyện Hoài Nhơn, Phù Mỹ) và khu vực 2 (khu vực phía nam gồm một số xã ven biển thuộc huyện Phù Cát, Tuy Phước và Tp. Quy Nhơn). Kết quả xây dựng bản đồ nhạy cảm môi trường ở 2 khu vực được thể hiện trong hình 3 và hình 4 .

Từ kết quả xây dựng bản đồ nhạy cảm môi trường đường bở tỉnh Bình Định, nghiên cứu đã xác định và khoanh vùng các khu vực cần ưu tiên xử lý khi có SCTD xảy ra tại Bảng 5 . Trong đó, khu vực ưu tiên phân bố rải rác dọc theo bờ biển từ huyện Hoài Nhơn đến Tp. Quy Nhơn. Khu vực phía nam tỉnh Bình Định (khu vực 2) có nhiều vị trí ưu tiên hơn, nguyên nhân ở đây có nhiều bãi ngư trường và bãi nuôi trồng thủy sản lớn phân bố tập trung ở vùng Vịnh Quy Nhơn, đầm Thị Nại thuộc huyện Tuy Phước; có nhiều rạn san hô diện tích lớn phân bố xung quanh hòn ven bò̀: Hòn Khô, Hòn Đất, Hòn Ngang, Cù Lao Xanh, Mũi Yến và đặc biệt ở đây có nhiều bãi tăm có giá trị kinh tế - du lịch tập trung ở ven biển Quy Nhơn. Kết quả này trùng khớp với những khu vực chịu ảnh hưởng bởi SCTD xảy ra trước đây đã được nêu ở phần đặt vấn đề, điều này chứng tỏ mức độ tin cậy cao của nghiên cứu, có thể hỗ trợ hiệu quả cho công tác ứng phó SCTD xảy ra trên vùng biển tỉnh Bình Định.

Bảng 5: Khu vực ưu tiên xử lý khí có SCTD xảy ra tại vùng biển tỉnh Bình Định

\begin{tabular}{|c|c|c|}
\hline Khu vực & Vị trí ưu tiên & Đặc trung vị trí ưu tiên \\
\hline \multirow{5}{*}{1} & $\begin{array}{l}\text { Cửa Tam Quan, xã Tam Quan Bắc, Huyện } \\
\text { Hoài Nhơn }\end{array}$ & $\begin{array}{l}\text { Tập trung nhiều bãi nuôi tôm lớn, dạng bờ thấp } \\
\text { phủ thực vật. }\end{array}$ \\
\hline & Bờ bắc xã Hoài Hải, huyện Hoài Nhơn. & Có bãi nuôi tôm lớn. \\
\hline & Mũi An Dũ, xã Hoài Hải - Hoài Nhơn & Có rạn san hô \\
\hline & $\begin{array}{l}\text { Bờ nam xã Mỹ Thắng, bờ bắc Xã Mỹ An, } \\
\text { huyện Phù Mỹ }\end{array}$ & Có bãi nuôi tôm \\
\hline & Huyện Tuy Phước & $\begin{array}{l}\text { Tập trung bãi ngư trường và bãi nuôi trồng thủy } \\
\text { sản lớn, đa dạng sinh học cao. }\end{array}$ \\
\hline \multirow{7}{*}{2} & Cửa Đề Gi, xã Cát Khánh, Huyện Phù Cát & Bãi nuôi trồng thủy sản lớn. \\
\hline & $\begin{array}{l}\text { Eo Gió, Hòn Nghiêm Kinh Chiểu, xã Nhơn Lý } \\
\text { - Quy Nhơn. }\end{array}$ & Bãi San Hô lớn. \\
\hline & $\begin{array}{l}\text { Đầm Thị Nại, Vịnh Quy Nhơn, huyện Tuy } \\
\text { Phước }\end{array}$ & $\begin{array}{l}\text { Tập trung nhiều bãi nuôi trồng thủy sản (tôm, cá), } \\
\text { nhiều thảm thực vật (cỏ biển) và các sinh vật nước } \\
\text { mặn lẫn nước ngọt. }\end{array}$ \\
\hline & Hòn khô, Mũi Yến, Nhơn Hải - Quy Nhơn. & Quần thể rạn san hô phát triển. \\
\hline & $\begin{array}{l}\text { Hòn Đất - Hòn Ngang, phường Ghềnh Ráng - } \\
\text { Quy Nhơn. }\end{array}$ & Rạn san hồ \\
\hline & Cù Lao Xanh, Xã Nhơn Châu - Quy Nhơn. & Rạn san hô \\
\hline & $\begin{array}{l}\text { Bãi tắm Đài Xuân và một số bãi tắm dọc bờ } \\
\text { biển Quy Nhơn. }\end{array}$ & Bãi cát trắng có giá trị du lịch cao. \\
\hline
\end{tabular}

\section{KẾT LUÂN}

Bản đồ nhạy cảm đường bờ phục vụ công tác ứng phó SCTD khu vực ven biển tỉnh Bình Định đã được xây dựng là một công cụ quan trọng phục vụ Kế hoạch ứng phó SCTD của tỉnh. Kết quả nghiên cứu cho thấy bãi triều phẳng phơi lộ (dạng 7$)$ và đường bờ đất ngập nước mặn $(10 \mathrm{~A})$ là dạng đường bờ chiếm ưu thế nhất thuộc ven biển tỉnh Bình Định. Môi trường biển tỉnh Bình Định có tính đa dạng sinh học cao với các bãi san hô, cỏ biển, rừng ngập mặn, cùng với các hoạt động nhân sinh đa dạng như: khu du lịch, bãi tắm biển, khu nuôi trồng thủy sản... Đây là các dạng tài nguyên được đánh giá có giá trị cao và cần được chú ý bảo vệ. Ngoài ra, nghiên cứu cũng đã xác định và khoanh vùng các khu vực cần ưu tiên xử lý khi có SCTD xảy ra, kết quả này có mức tin cậy cao, giúp hỗ trợ hiệu quả cho các cơ quan quản lý triển khai những phương án bảo vệ kịp thời, nhằm ứng phó khi có SCTD xảy ra trên vùng biển tỉnh Bình Định. 


\section{BẢN ĐÔ NHẠY CẢM MÔI TRƯờNG ĐƯờnG BÒ}

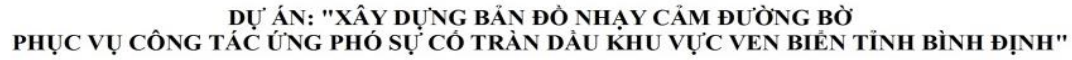

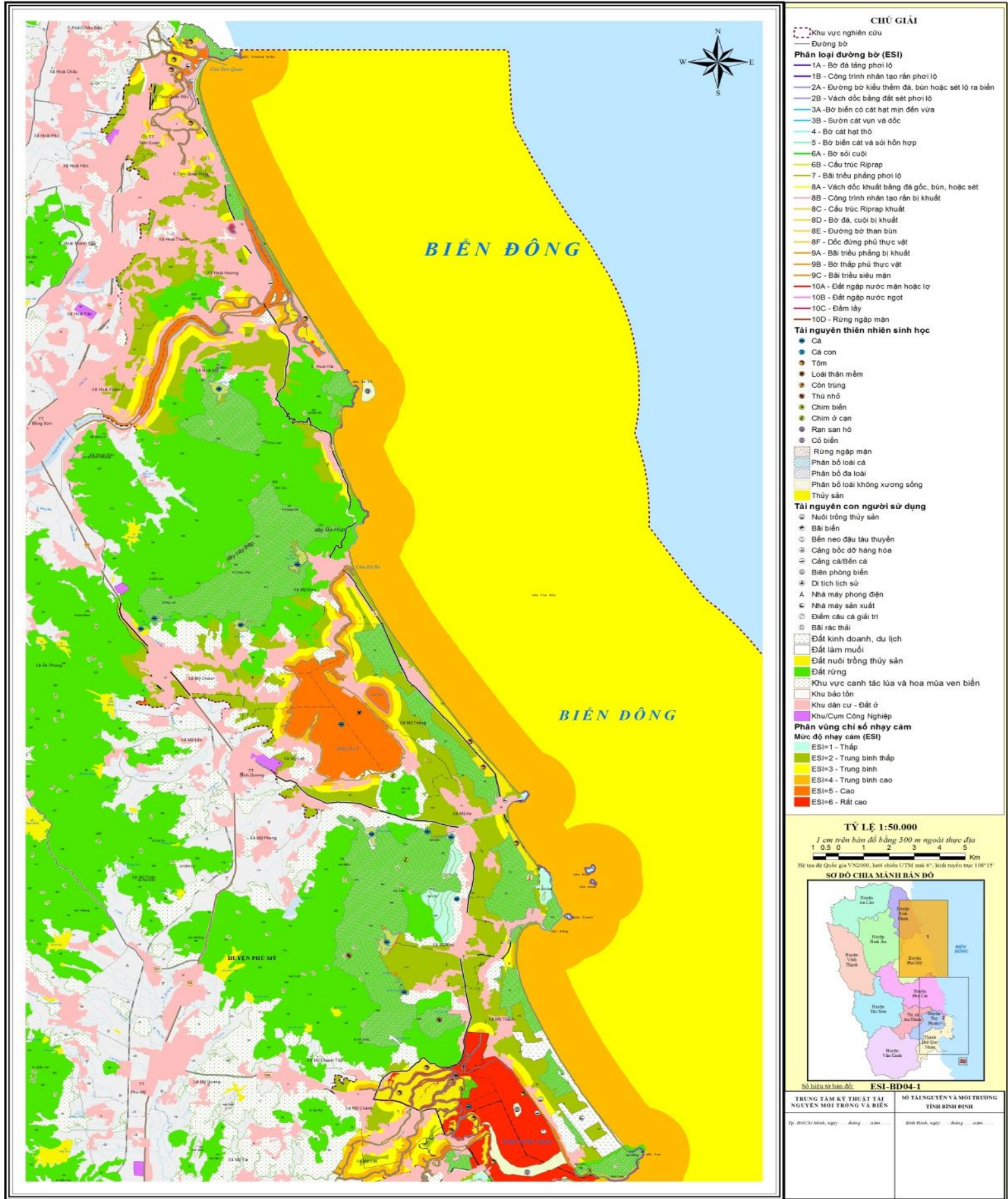

Hình 3. Bản đồ nhạy cảm môi trường đường bờ khu vực 1 


\section{BẢN ĐỒ NHẠY CẢM MÔI TRƯờnG ĐƯờnG BÒ̀}

DƯ ÁN: "XÂY DƯNG BẢN ĐỎ NHAY CÄM ĐƯ⿱宀NG BỜ

PHụC VỤ CÔNG TÁC ÚNG PHÓ SỰ CÓ TRÁN DÂU KHU VỰC VEN BIẺN TİNH BİNH ĐỊNH"

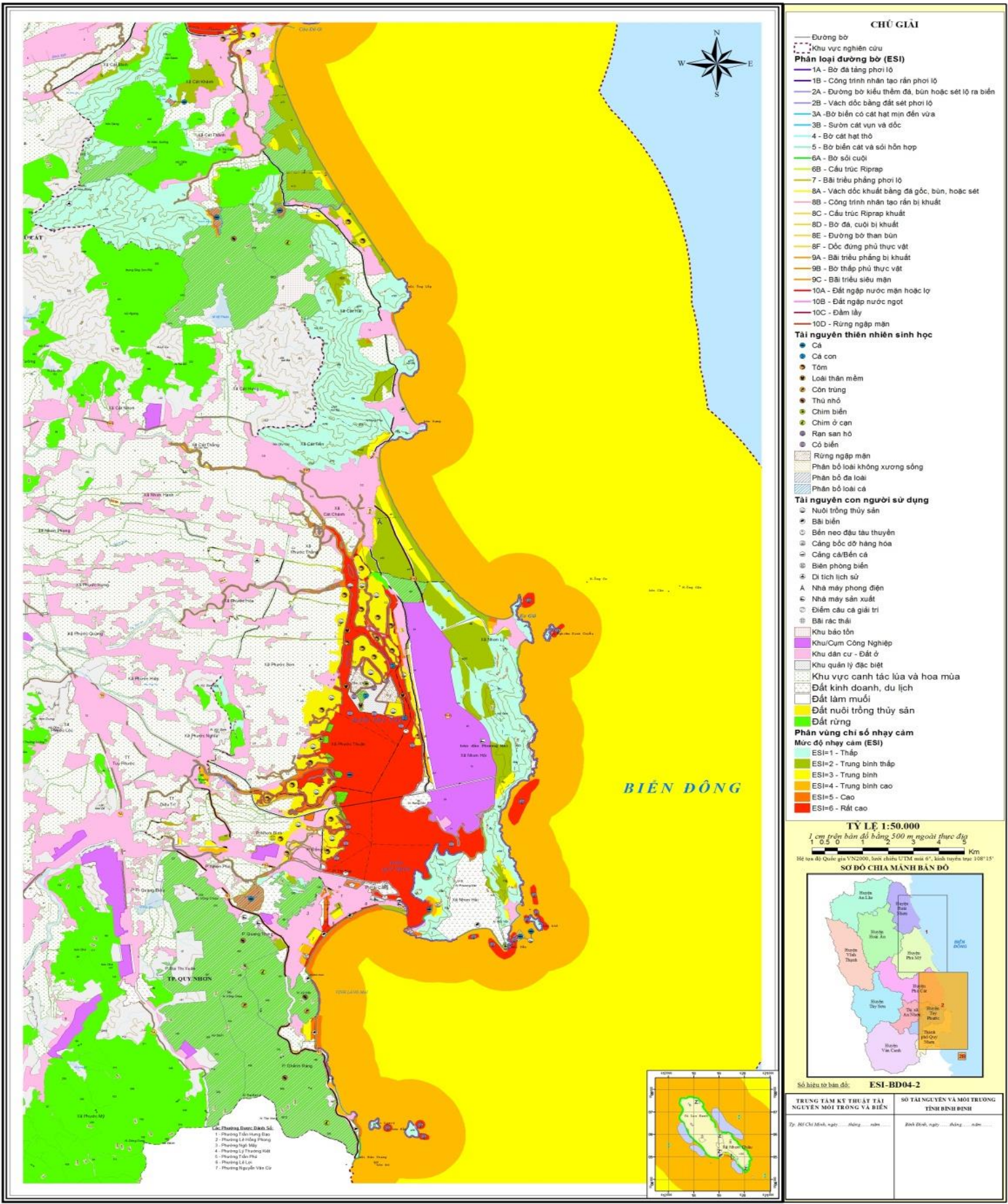

Hình 4. Bản đồ nhạy cảm môi trường đường bờ khu vực 2

\section{LÒ̀I CÁM ƠN}

Bài báo là kết quả nghiên cứu từ Dự án "Xây dựng bản đồ nhạy cảm môi trường đối với SCTD ven biển Tỉnh Bình Định”. Tác giả chân thành cám ơn Sở Tài Nguyên và Môi Trường tỉnh Bình Định đã tài trợ kinh phí. 

TỈNH BİNH ĐỊNH

\section{TÀI LIỆU THAM KHẢO}

[1] NOAA, Environmental Sensitivity Index Guidelines version 3. NOAA Technical Memorandum Nos OR and R11. Hazardous Materials Response Division, National Ocean Sevice. Seattle, WA: 192p, 2002.

[2] P. W. M. Souza Filho, F. D. Goncalves, F. P. de Miranda, C. H. Beisl and E. de Faria Almeida, Environmental sensitivity mapping for oil spill in the Amazon coast using remote sensing and GIS technology, IGARSS 2004. 2004 IEEE International Geoscience and Remote Sensing Symposium, Anchorage, AK, vol.3, pp. 1565-1568, 2004.

[3] D. Nachite, N. Del Estal Domínguez, A. El M'rini, G. Anfuso, Environmental Sensitivity Index maps in a high maritime transit area: The Moroccan coast of the Gibraltar Strait study case, Journal of African Earth Sciences, Volume 163, 103750, 2020.

[4] Gil-Agudelo, Diego L, Nieto-Bernal, Ramón-Alberto, Ibarra-Mojica, Diana-Marcela, Guevara-Vargas, AnaMaría, \& Gundlach, Erich, Environmental sensitivity index for oil spills in marine and coastal areas in Colombia, C.T.F Cienc. Tecnol. Futuro, 6(1), 17-28, 2015.

[5] Đào Nguyên Khôi, Phạm Thị Lợi, Hoàng Trang Thư, Nguyễn Văn Hồng, Xây dựng bản đồ môi trường đường bờ ứng phó sự cố tràn dầu trên địa bàn huyện Cần Giờ, Sci. Tech. Dev. J. - Nat. Sci, 3(1):29-37, 2019.

[6] Nguyễn Văn Phước, Nguyễn Thị Thu Hiền, Bản đồ nhạy cảm môi trường khu vực từ Bà Rịa Vũng Tàu đến Cần Giờ TP. Hồ Chí Minh, Tạp chí môi truờng, Chuyên đề II, p.47-53, 2019.

[7] Đinh Bá Phú, Thái Cẩm Tú, Lương Kim Ngân, Xây dựng bản đồ nhạy cảm môi trường và bổ sung kế hoạch ứng phó sự cố tràn dầu tỉnh Thanh Hóa, Dầu khí 2017, số 11, p.58-64, 2017.

[8] Nguyễn Ngọc Sơn, Đinh Thị Nguyệt Minh, Lương Kim Ngân, Bản đồ nhạy cảm môi trường và phân vùng ưu tiên dãy ven bờ biển tỉnh Thái Bình đối với sự cố tràn dầu, Dầu khí 2015, số 8, p.58-64, 2015.

Ngày nhận bài: 13/05/2020

Ngày chấp nhận đăng: 14/01/2021 